\title{
Museological Approaches to the Management of Digital Research and Engagement: The African Rock Art Image Project
}

\author{
Helen Anderson • Elizabeth Galvin • \\ Jorge de Torres Rodriguez
}

Published online: 2 June 2018

(C) The Author(s) 2018

\begin{abstract}
The African Rock Art Image Project at the British Museum has documented and disseminated c. 24,000 digital images of rock art from throughout the continent, donated by the Trust for African Rock Art (TARA). The images were registered into the British Museum's permanent collection and treated as objects in their own right, not just digital reproductions of objects. As a wholly born-digital collection, this led to several opportunities and challenges for documentation, dissemination, and digital humanities outputs, including a fully searchable database, social media, website, 3D modelling and printing, and virtual reality, to name a few. Increasingly, digital technologies are being used in standard archaeological research and practice. From digital photography to larger 3D modelling/scanning, the volume of data being created by archaeologists is increasing exponentially, as is the potential for these outputs to change research and community engagement. But with the massive amounts of data being created, are researchers documenting and disseminating their data to their full potential? Here, traditional museum practices of cataloguing, storing, and public engagement can
\end{abstract}

H. Anderson · E. Galvin $(\bowtie) \cdot$ J. de Torres Rodriguez Department of Africa, Oceania and the Americas, The British Museum, Great Russell Street, London WC1B3DG, UK e-mail: EGalvin@britishmuseum.org

H. Anderson

e-mail: HAnderson@britishmusem.org

J. de Torres Rodriguez

e-mail: JdeTorres@britishmuseum.org inform archaeological practice to use these data collections for both scholarly research and community engagement. Through a critically reflective description of the work and challenges of the project, this paper argues that there are significant benefits to be gained by engaging digital rock art projects with established museum thinking and practice.

Résumé Le projet "African Rock Art Image Project" du British Museum a permis de documenter et diffuser environ 24.000 images numériques d'art rupestre provenant de tout le continent, offertes par l'organisation "Trust for African Rock Art" (TARA). Les images ont été enregistrées dans la collection permanente du British Museum et traitées comme des objets à part entière, et non pas seulement comme de simples reproductions numériques. Cette collection entièrement numérique a débouché sur plusieurs opportunités et défis pour la documentation et la diffusion, notamment une base de données entièrement consultable, les médias sociaux, le site Web, la modélisation et l'impression 3D, et la réalité virtuelle, pour n'en citer que quelques uns. De plus en plus, les technologies numériques sont utilisées dans la recherche et la pratique archéologique. De la photographie numérique à la plus grande modélisation / numérisation $3 \mathrm{D}$, le volume de données créé par l'archéologue augmente de façon exponentielle, de même que le potentiel de ces productions à changer la recherche et l'engagement communautaire. Mais avec les quantités massives de données créées, les chercheurs documentent-ils et diffusent-ils leurs de façon optimale? 
Ici, les pratiques muséales traditionnelles de catalogage, de stockage et d'engagement du public peuvent informer la pratique archéologique de l'utilisation de ces collections de données pour la recherche scientifique et l'engagement communautaire. À travers une description critique du travail et des défis du projet, cet article soutient qu'il y a des avantages significatifs à obtenir en engageant des projets d'art rupestre numérique avec la pensée et la pratique muséologique.

Keywords Digital technology · Museum practice . Community engagement $\cdot$ Rock art

The sheer volume of digital data being created by rock art scholars has the potential to fundamentally change the way the field approaches issues such as documentation, dissemination, and engagement. From digital photos to full 3D scans, these outputs help both scholars and local communities to understand and explore this heritage. The African Rock Art Image Project (ARAIP) at the British Museum is one of a number of initiatives established to promote the collation and cataloguing of rock art sites throughout the continent, their digital outputs, and the involvement of African communities in the protection of their heritage.

In 2013, the British Museum acquired c. 24,000 images from the Trust for African Rock Art (TARA) based in Nairobi, Kenya. Covering 20 countries and many of the most important rock art sites throughout the continent (Fig. 1), the collection provides an instructive cross-section of the main styles, chronologies, and themes of African rock art, as well as additional images of landscapes, ethnographic or archaeological materials. For a period of 5 years, the collection has been described, catalogued, and incorporated into the British Museum online collection, and disseminated through different websites and social media. Each of these images is registered into the British Museum's collection, and as such, is treated with equal curatorial care as a physical object in the collection.

Museum practice involves understanding which objects to collect, how to store them, and making them available to both the academy and the general public (MacDonald 2006). This is the same in the digital archaeology sphere where it is also imperative to understand how digital photographs/outputs should be shared, stored, disseminated and made available to different communities. Such museological thinking and practice informed the project about ways to preserve, research, and share Africa's rock art. Applying traditional institutional practices and theories of engagement, preservation, and access to the use and management of digital technologies in this context has provided some insights into reciprocal practices with researchers in the field. The position we propose here is that traditional curatorial approaches to documentation, dissemination, and outreach can be applied to the wider archaeological use of technology in rock art to ensure that collections are stored, shared, and engaged with to their full potential.

\section{Rock Art Catalogues}

ARAIP is not the first initiative to approach the cataloguing of rock art images. Rock art websites, such as TARA and the Bradshaw Foundation, provide useful resources for the knowledge and dissemination of African rock art but do not constitute comprehensive catalogues of images. The largest catalogue is the South African Rock Art Digital Archive (SARADA), a project developed by the Rock Art Research Institute at the University of the Witwatersrand, which comprises c. 300,000 images and related materials. Other projects include the African Archaeological Archive (AAArC) in Cologne (c. 60,000 images) or the World Archive of Rock Art (WARA), based in the Centro Camuno di Studi Preistorici Italy (c. 150,000 images). Other databases are focused on more specific collections, such as the Rock Art Archive of the Database of the Frobenius Institute (Frankfurt) which focuses on the early to midtwentieth-century rock art image collections of Leo Frobenius and affiliated scholars (http://www. frobenius-institut.de/en/collections-and-archives/rockart-archive). Another is the Libyan-Berber inscriptions online database (LBI) which specialises in rock art representations in North Africa and the Canary Islands that contain Libyco-Berber script (http://www. institutum-canarium.org/lbi-project/objectives.php).

However, ARAIP is the first time that such a catalogue has been managed by a museum on this scale, a situation which requires a different approach to the way the collection is documented and used. The images stored at the British Museum are treated as objects in their own right, not just digital reproductions of objects. While other catalogues have been built by organisations 
Fig. 1 The countries covered by the African Rock Art Image Project and the geographical spread of known major rock art sites (images in full colour online)

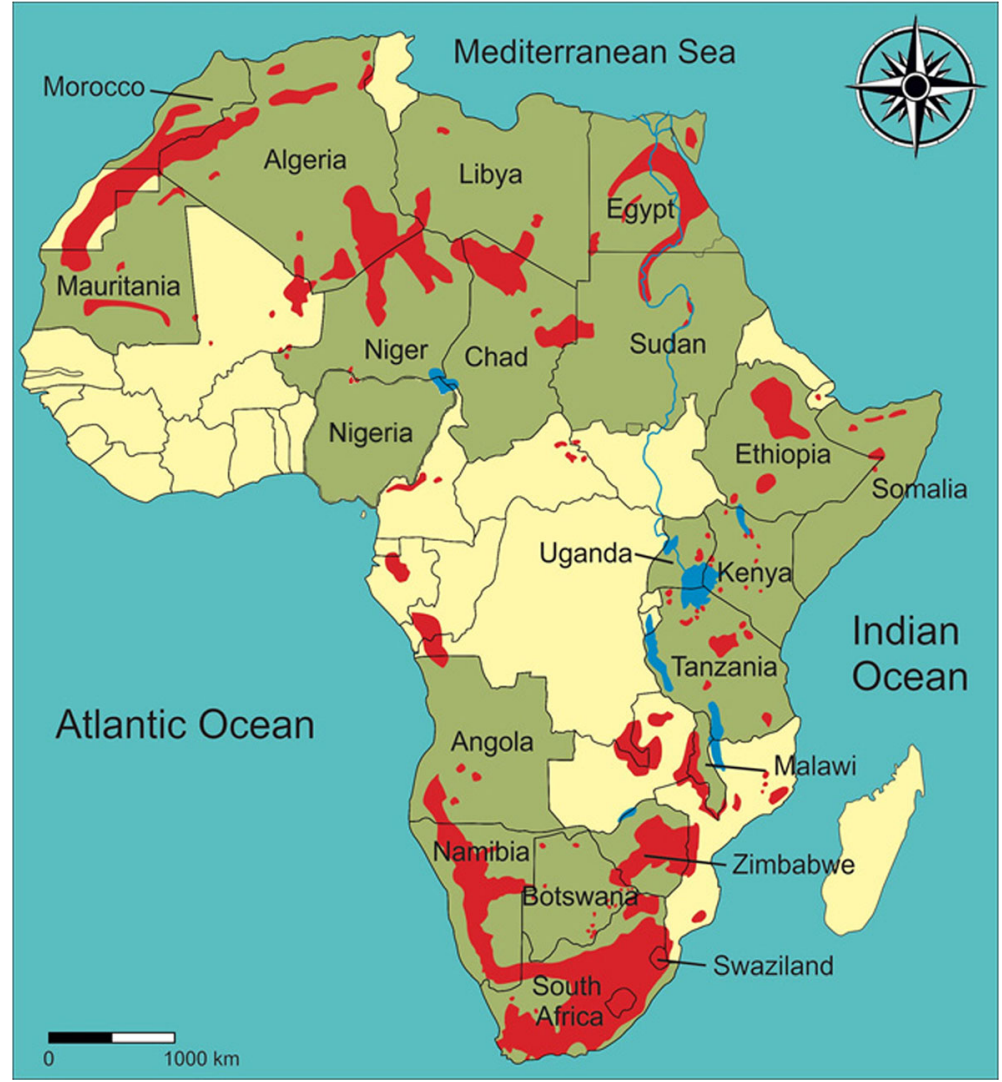

whose main interests are to protect, preserve, and use the information for research purposes, such as SARADA, the role of the British Museum also includes the dissemination of the collection to the general public, worldwide. This key difference establishes a diverse set of strategies, tools, and conceptual approaches about how, and to what purpose, the collection is used.

Although it is true that a huge amount of information has been processed and made available online during the last decades; the characteristics, accessibility, and information provided by different websites vary substantially, especially regarding the contextualization of images. Information provided consists mostly of dates, locations (often just the country name), reference numbers, and, depending on the database, additional information such as the probable chronology or the kind of original document in the database. As a result of the lack of contextualization, the aforementioned databases can be considered useful as repositories of information, but they can be intimidating to the general public and therefore mainly used by specialists (di Lernia 2018). Moreover, some catalogues are no longer updated, risking obsolescence in terms of software and online maintenance. Most of the problems regarding accessibility of these catalogues lie in their origins, as they were never conceived as a part of a dissemination project and aimed at a more specific, professional audience. Being part of a museum strategy, the scope of ARAIP is radically different and requires an equally distinctive approach to the scope of the catalogue and the strategies to make it public.

\section{Store, Protect, Catalogue: Curating a Digital Collection}

One of the most immediate expressions of increased digital technology in archaeology has been the proliferation of images that are taken, stored, uploaded, and shared throughout the world. The advent of digital cameras has had a huge impact on archaeological fieldwork practices making the process of documentation much simpler and quicker, but also resulting in the creation of thousands of images. This wealth of digital data raises significant curation issues, not only for museums and archives (Cunningham 2008), but for archaeologists, 
who increasingly are the curators of their own fieldwork archives. With so much information being created, it raises traditional musicological questions: what is able to be collected (MacDonald 2006), stored (Abt 2006), catalogued (Roberts 1991), and displayed (Prezosi 2006) and how can this be made usable by scholars and the public (Crooke 2006; Kaplan 2006). From this perspective, ARAIP is a pilot project for the British Museum. The cataloguing of the wholly digital collection illustrates some of the challenges faced by museums (Poyner IV 2010): how to integrate a digital collection in a cataloguing system conceived for physical objects, and how to ensure that these digital objects are properly stored and curated.

\section{Cataloguing the Digital}

As one of the oldest museums in the world, the British Museum has continuously modified its cataloguing systems to adapt to new technologies and to make public its collections (Pett 2012). The computerised database was started in 1976 and the current cataloguing system, MI+, was implemented in 2017, replacing the previous bespoke system, Merlin, launched in 2000 (Szrajber 2008: p. 3). Another database, Odin, currently acts as the digital asset manager for the British Museum. MI+ and Odin are fully integrated, creating a bilateral system for the British Museum's catalogues (Galvin et al. 2017: p. 578). The third step of the system is Collection Online (COL), the web version of its collection database (Szrajber 2007) open to the public and currently holding more than 3,500,000 objects.

The current cataloguing system of the British Museum has to accommodate an incredible variety of objects, materials, places of origin, and cataloguing criteria, and be able to deal with the idiosyncrasies of the c. 8 million objects in the different curatorial departments in the Museum. This situation introduces some challenges in the system: for example, it is impossible to store a thesaurus of every word related to the worldwide scope of the Museum, and therefore, terminologies for describing the objects are developed in-house and added when necessary by curators with final approval of the documentation staff (Szrajber 2008: pp. 5-6). Another problem is the large discrepancy in terms of quality and accuracy of the records (Szrajber 2008: p. 2), because the original databases were conceived for internal use only; or the outdated references due to the advance of research and the changes in terminologies and styles of describing the objects.

An imperative part of the project was not just documenting digital objects to harmonise with the existing physical object cataloguing standards, but also to ensure uniformity and long-term digital preservation. As such, the project implemented standardised file formats, long-term storage solutions, and appointed a Digital Preservation Manager who sat within the Information Services Department at the British Museum to ensure the conservation and storage of the digital collection was at the highest standard. For full specifications of the decisions and implementation of digital cataloguing, storage, and preservation, please see Galvin et al. 2017.

The ingestion of the ARAIP collection in the cataloguing system of the British Museum has followed the guidelines of the documentation department, but as a wholly digital project, presents a unique set of opportunities and challenges (Bertacchini and Morando 2013). Working in partnership with the documentation department, ARAIP developed a series of cataloguing guidelines for digital objects based on adapted previous standards of documentation and internationally recognised digital and rock art glossaries to increase uniformity of the records. In some cases, such as the southern African rock art collections, collaborative work has been conducted with other institutions, such as SARADA, to harmonise search terms and locations geography and to increase searchability and access across the respective databases.

\section{The Challenge of Storage}

Undoubtedly positive, the increase of digital technologies in archaeology also raises some questions about how the vast amount of photographs and many other digital objects are stored and made available to the public. Appropriate storage of images is becoming a major issue of debate and the object of an increasing number of initiatives (www.data-archive.ac.uk/home; www.tdar.org/about/; archaeologydataservice.ac.uk/ or www.dpconline.org/ -to cite some examples) and publications (Brin et al. 2013). Digital objects cannot simply be stored and neglected: changes in formats can make files unreadable, software becomes outdated, and even with a careful storage policy loss of information can occur during back up and copying processes. That 
means that even when suitable storage is in place, the data require continuous monitoring and digital curators must ensure these objects are properly preserved for future generations. As the digital revolution progresses, the existence of digital objects - not only just images, but also sound recordings or many documents of the grey literature (these include publications such as research and annual reports, conference proceedings, field notes, presentations, etc. (see Evans 2015) — will be a common feature in most museums and archives and will require the development of new policies to deal with this new situation.

\section{Balancing Storage and Volume}

The problems of storage and curation are especially evident in archaeology. Usually only a very small sample of photographs is finally included in archaeological reports and scientific publications, with most of the images remaining on personal storage devices, often without proper cataloguing and monitoring, and no guarantees that the data will be ever available to the world. This potential loss of information is especially risky (Conway 2010) as it is usually the only remaining information about the material context in which the archaeological materials were recovered. In the case of rock art, the fragility of many depictions and their location in places where political unrest prevents access to the sites will unfortunately make digital collections a fundamental tool with which to study rock art in many African regions, at least in the short term. Therefore, the proper storage and curation of digital data in archaeology is quickly becoming not just something desirable, but an ethical responsibility (Brin et al. 2013). The risk is even more evident considering the decreasing average life of electronic devices (Ashley and Perlingieri 2012: p. 662), meaning that an astonishing amount of archaeological information could be lost forever in the next few decades. Paradoxically, it is the overwhelming volume of data being created that leads to relaxed approaches in its storage, documentation, and curation (Henning 2006), that could in turn lead to the loss of information on an unprecedented scale.

\section{Dissemination: Taking the Collection to the World}

The systematic organisation and cataloguing of a digital collection is clearly important, but ensuring that the public are able to access and understand it is also an institutional and disciplinary responsibility. One of the criticisms of some rock art databases is that they are simply storehouses and that we should avoid "saving terabytes of beautiful rock art images in the cloud but without any context or archaeological background" (di Lernia 2018). Therefore, the role of the website is vital to help audiences to contextualise and learn about the collection across the continent.

For the ARAIP, while the collection of images acts as a reference resource for specialists, the contextualization and dissemination of the collection was a critical concern. The goal of making museum content available to the general public via a Web-based portal emerged in the mid-1990s and has resulted in the introduction of the term Cybermuseology, into General Museology theory to advance the idea of the efficient use of digital media by museums (Langlais 2005; Leschenko 2015). General Museum theory refers to the interdisciplinary ideas and practices needed to operate a museum, from collections management to the role of museums in society (Preziosi and Farago 2003; MacDonald 2006; Schubert 2009; Message and Witcomb 2015). The main goal of Cybermuseology is to disseminate information created within a museum context using the possibilities provided by Information and Communications Technology (ICT). The prefix "cyber" is not limited to the use of the Internet but includes the use of computers for educational purposes, virtual museums, mobile tours, digitisation, 3D printing, social media strategies, and others (Leschenko 2015: p. 239).

In 2015, the British Museum published their Preliminary Report on the Museum of the future (Motf) initiative, (http://www.britishmuseum.org/whats on/museum_of_the_future.aspx), an unprecedented engagement process with the public about the Museum's purpose going forward. In making recommendations to help improve the visitor experience, the role of the digital was firmly placed at the heart of the Motf programme, reviewing the Museum's website and other digital channels and assets, with the explicit aim of improving the experience for online users. It is within this institutional discourse and climate that ARAIP initiated its digital strategies aimed at informing and engaging audiences across the world, using innovative and rapidly developing digital technologies. 


\section{Online Dissemination}

Rock art research websites have taken a variety of forms and are dependent not only upon the aims and objectives of the specific project, but are designed in relation to their target audience, often specialist or academic. Research by Ross and Terras (2011), into user perspectives, search strategies and the general use of museum digital resources by scholars has shown that academic users value digital resources highly and use them extensively in their research process, with high expectations that museums with large collections, such as the British Museum, will disseminate their collection online. Three of the main online rock art collections, SARADA (NRF 2009), WARA (Anati 2004) and the Frobenius Institute (Kaneko 2015; (see also Galvin et al. 2017: pp. 573-576 Kohn 1998) for more information) have been specifically designed for, and are demonstrably directed at, the academic and scholarly community. The motivation for these databases is based on the preservation of visual and textual documents of rock art and in making these resources available for the worldwide research community. However, as outlined above, the scarcity of associated contextual information is problematic. The lack of contextualization characterises the databases as repositories of data, comprehensible to specialists and experts rather than as sites of learning.

Therefore, in line with the Museum of the future initiative, a key intention concerning the website presence is the contextualisation of the imagery in ways that inform audiences about the geography, history, archaeology, and anthropology of rock art research (http://africanrockart.britishmuseum.org). The aim is to allow the non-specialist to explore rock art from across the continent and to make informed observations, judgements and comparisons. The proximity of a museum's collections to its audiences, a global audience, is a critical component in the success of a museum (Coffee 2007; Kelly and Fitzgerald 2011; Stein et al. 2013; Falk 2016). The British Museum's motto of “A Museum of the World for the World", refers to its aims of putting "the collection to work for the citizens of the world" (British Museum Annual Review 2004/2005: p. 5). This is both a responsibility and an opportunity for a digitalonly collection in terms of audience reach. The Museum's audience is one of the most diverse in the world, comprising a huge variety of ethnic, language, educational, cultural, and religious backgrounds, and increasingly curators and museum professionals have to find innovative ways to attract new audiences and engage existing ones (British Museum Annual Review 2016/ 2017: p. 6).

As such, in writing content for the website, the team has tried to present a comprehensive approach to the collection, based on two main axes: geographical and thematic. Geographically, the collection is organised into three main areas of the continent (Northern, Southern, Central/Eastern), with a general overview of the rock art in that area (see Fig. 2). Web content includes more detailed information on the geography of the country, a history of rock art research, styles, themes and chronology; and featuring details of a key site that exemplifies the rock art of the region.

These geographic articles are augmented with extra information concerning dating and chronologies, the origins of art in Africa (the most viewed page in 2015 outside the homepage) and techniques of production, to improve understanding and to enhance audience experience. As the project progressed, the transversality required to study some of the styles, depictions, and themes of the collection has led to a score of entries dealing with more specific aspects of rock art, from camels, chariots, rhinos, and warrior figures to hairdressing, fishing, landscapes, and Libyco-Berber script (Fig. 3).

Indeed, as di Lernia (2018) acknowledges, audiences that are not specialists in rock art research can be "frustrated by the lack of contextual information" and this project actively and intentionally attempts to abrogate such a deficiency. Although not an intentionally academically oriented project, at the time of publication the website articles include 190 academic citations on rock art covering the whole continent, demonstrating the project's commitment to the proper contextualisation and referencing of the images (Fig. 4).

Driving online engagement is the issue of accessibility. One of the main aims of this project is to ensure that audiences in local and source communities throughout Africa have the capability to access this collection. The diversity of internet access across the continent adds to this challenge. Africa has rapidly moved from a 'mobile first' to "mobile only" market (see Ayemoba 2016). Between 2012 and 2015, the cost of smartphones has decreased by almost half (GSMA Report 2016: p. 14) and while relatively high-speed internet is available in many major urban environments, expenditure on data can be prohibitively expensive. As such, the success or failure of online products in Africa is dependent upon 


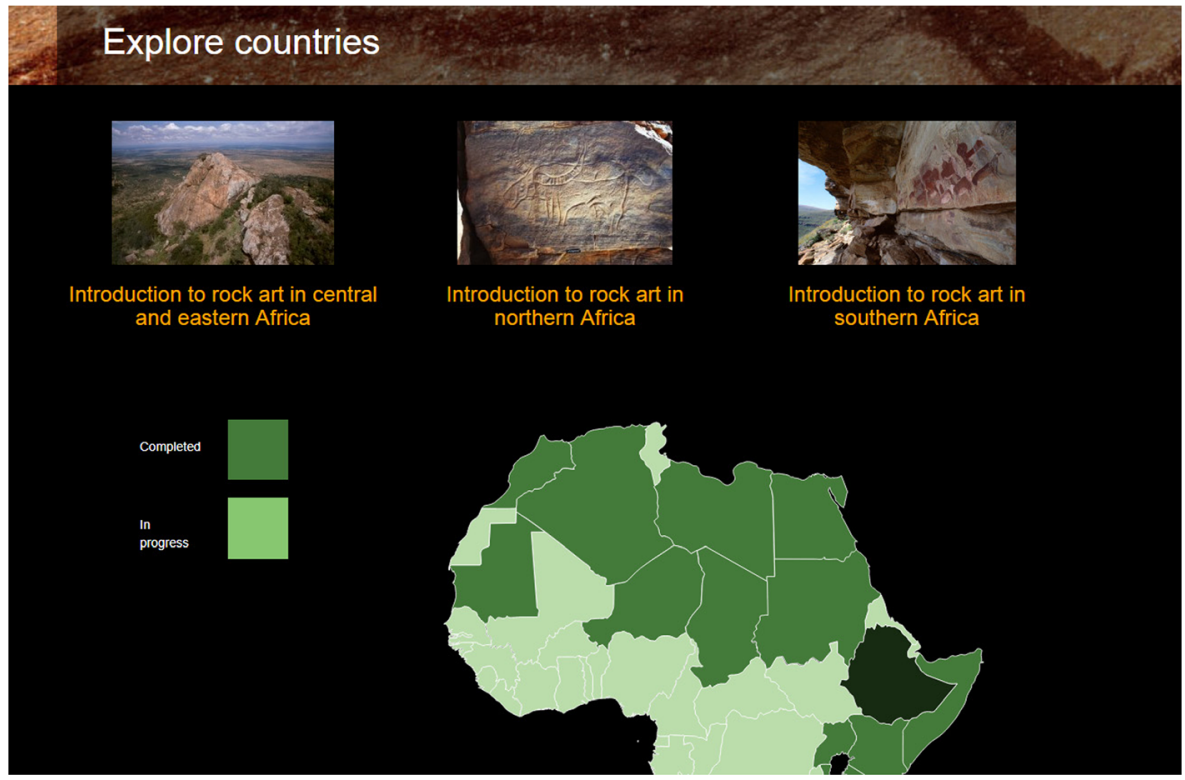

Fig. 2 Screenshot from the ARAIP website showing the Introduction to regional rock art information http://africanrockart.britishmuseum.org

download speeds and file size (Ayemoba 2016). In light of this situation, the project team conducted a survey of 45 African countries, identifying each country's engagement in social media and average broadband speed. This study (see Galvin et al. 2017: pp. 587-588) has allowed the project to establish a digital strategy focused on African audiences. As a result of this study, different strategies have been proposed and adopted to facilitate access, i.e., the use of lower resolution images for specific social media platforms, and the development of low bandwidth (slightly reduced versions for the website with highly compressed JPEG images) in countries with the slowest connections.

While traditional web engagement is important, the distribution and immense popularity of social media is an immediate and responsive platform through which museums can increase dissemination and access to their collections (Gu 2012; Pett 2012; Taylor and Gibson 2017). In 2010, the British Museum was active on just two social media platforms (Facebook and Twitter) with fewer than 50,000 followers in total. It now has accounts across 9 social media platforms, with over 1.6 million

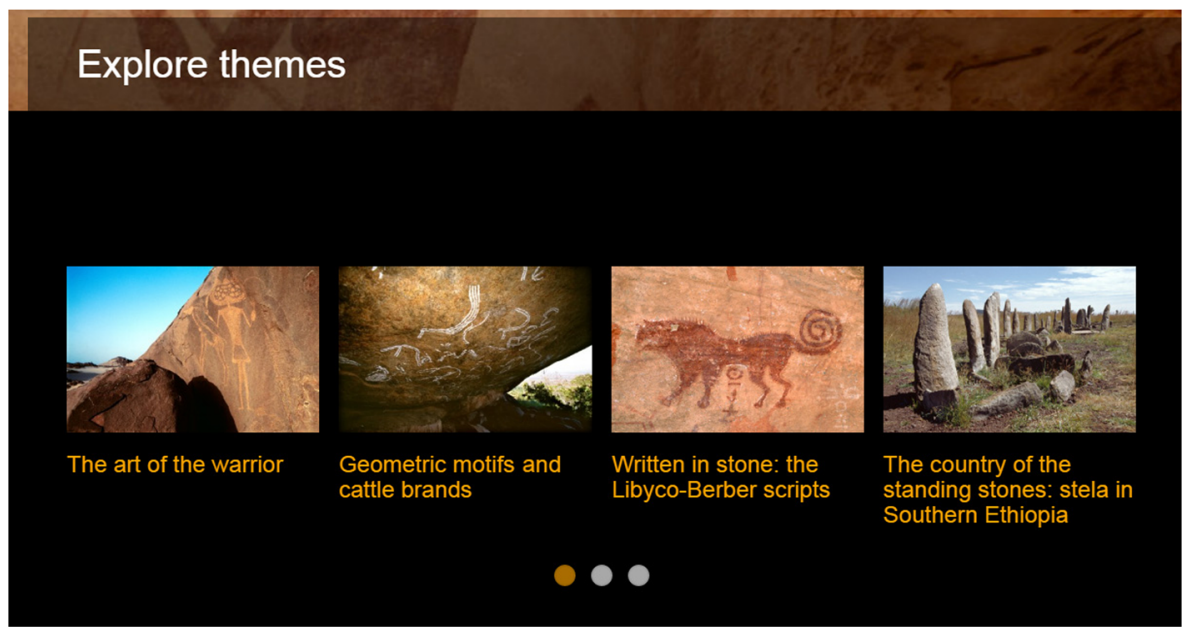

Fig. 3 Screenshot of ARAIP website showing selection of themes articles http://africanrockart.britishmuseum.org 


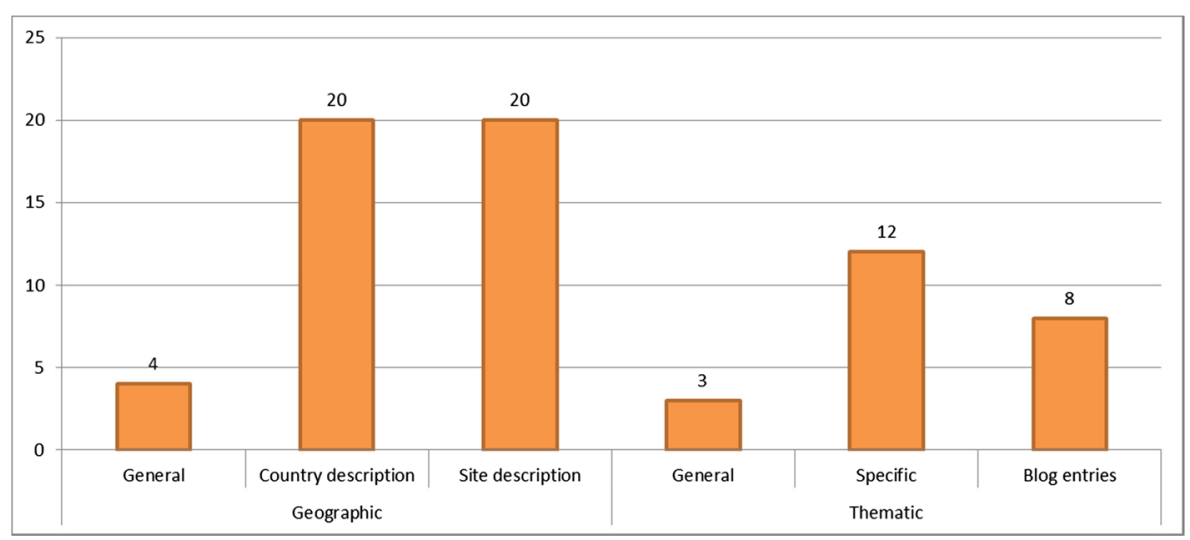

Fig. 4 Website articles published in the African Rock Art Image Project (67 in total)

followers (British Museum Annual Review 2014/2015). Moreover, the huge online presence of the British Museum - with more than 43.7 million virtual visitors in 2014 - played a key role in publicising information about the project (Pett 2012). The project is active on Facebook, Twitter, Instagram, Google+, Pinterest, and Tumblr, with regular social media promotion. Using Google Analytics, it has been possible to analyse the ways in which the website is being viewed by internet users, allowing the project team to evaluate popular features as well as identify how people are guided to the site, and how the project might improve and encourage web visitors. Social media is the largest single source of visits to the project website; in some cases, a feature promoted on the Museum's social media channels can quadruple same day visits to the site, making this a productive and easy way to promote the project, new website content and updates. Interestingly, some of our most viewed pages are the project's website articles, such as Fishing in the Sahara (http://africanrockart. britishmuseum.org/\#/article/gone-fishing) and Camels in Saharan rock art (http://africanrockart. britishmuseum.org/\#/article/camels-in-saharan-rockart), suggesting that extended research pieces are a key asset to the site.

\section{Challenges of Online Access}

The challenges of dissemination are numerous and despite attempts to create an accessible and informative website, there are clearly areas that need addressing. For example, despite the motto of being a "Museum of the World", the rock art website is only available in English, and as such may be unusable by a large number of audiences. This is an area for concern and future development, and collaboration with rock art researchers in the field is vital for successful linguistic integration and interpretation (see Challis 2018, this issue).

While public learning may contribute to the democratisation of heritage, museums need to be selfreflexive in the decisions made in terms of the selection of information, images, and accessibility. ARAIP is no exception and has had to make judgements on the inclusion of certain images and data; decisions relating to their appropriateness and/or whether such information should be in the public domain. As active participants in the democratisation process, we "are party to creating the standards, norms, and methods for how to proceed when making heritage democratic" (Rodéhn 2015: p. 96). While we advocate in this context that museological practices may be valuable tools for rock art researchers, the advancement of cultural democracy must necessarily be collaborative between, museums, researchers and their engagement with source communities.

A hope or expectation for an online collection is its potential to inform source communities about their heritage and promote its preservation. While the provision of contextual information and low bandwidth images can contribute to this goal, the relationship between rock art researchers and local communities in heritage management is a critical one for conservation and preservation (see Challis 2018; Deacon et al. 2018; Namono 2018; Quesada 2018, this issue;). This one-to-one relationship cannot be superseded by a digital presence, but the benefits of web-based and social media digital engagement projects can be enormously helpful in dissemination and for raising awareness. 
Outreach: Using Digital Technologies for Engaging Audiences

Documentation and availability online are essential for audiences to access information about rock art. In addition, harnessing digital technologies for audience engagement can add tremendously to the understanding and experience of rock art collections. Photographs of rock art do not always convey the importance of place (Henry 2007: p. 44), but virtual tools can help mitigate this (Lee 2004: p. 34). While catalogues, introductory websites, and social media can direct the audience to gain information about rock art in general, archaeologists have the potential to positively engage with the public by sharing their digital rock art outputs, such as photogrammetry and virtual representations in addition to standard photographs. Indeed, Cameron (2007: p. 57) proposes that "the value of the 'real' increases when digitized, enhancing its social, historical, and aesthetic importance, owing to the resources required in the compilation of a 3D rendering, and through distribution". Many of these outputs were created using low- or nocost solutions as well as attempting to be as lowbandwidth as possible to engage local communities in areas in Africa where internet speeds may not handle large file outputs. In a time where "community engagement" is increasingly becoming a requirement of funding bodies and senior management, archaeologists can use these scholarly digital outputs to engage new audiences with Africa's rock art.

\section{D Modelling}

Photogrammetry and 3D scanning/modelling have been an effective method of archaeological research for over a decade (Allen et al. 2004; Fritz and Tosello 2007; Kuper 2013; Bennet et al. 2016; see Urcia et al. 2018; Quesada 2018, in this this issue for current examples of 3D modelling in rock art). It allows for contextualisation and understanding that photos alone cannot provide. However, these models are usually done through meticulous and methodical photography and scanning, thus requiring extensive time and equipment on site. Most museum models are achieved by taking hundreds of photographs that can be layered in various software programs (such as Agisoft Photoscan).

As a wholly digital project, it was necessary to be experimental to see what could be achieved by using existing photographs. Could photographs, some of which were taken on film in the 1980s and 1990s and later scanned, provide enough data to create usable 3D models for engagement? Without full measurements and scales, the models would not be scientific reconstructions, but they could provide enough detail and contextualisation for both scholarly and general audience applications.

Initial trials were undertaken in 2014. A well-known engraving of a crocodile in the Messak Setafett (Fig. 5) was chosen for a number of reasons: firstly, there were 22 photos of this one engraving, which, at the time, provided a greater diversity of angles and details. Secondly, the images were taken at different points over a day, which gave better definition and differentiation of the shadows and highlights of the engraving. Combining the images in Agisoft Photoscan, the project was able to create a 3D-effect model by plotting the images against each other in the $\mathrm{X}, \mathrm{Y}$ and $\mathrm{Z}$ axis.

With the digital and technological industries changing and developing so fast, it was necessary to start with proven technological outputs to take them one step further. Even at the outset of the project 3D modelling was considered a "mature resource" as opposed to an experimental output in digital terms because of the proliferation of low cost devises, improved accuracy, and the increase of open source solutions (Richards et al. 2013: p. 315), but photogrammetry techniques were dependent upon the provision of a suite of born-digital standardised photographs. This has changed to the extent that only small numbers of historical photographs (less than six) are sufficient to provide high quality, accurate results. Completed 3D models were put on Sketchfab (www. sketchfab.com), a free social media site dedicated to creating and sharing 3D models (Fig. 6). There, audio tracks and annotated models allow visitors to understand more about the context of the rock art as well as see fine details that may have been missed in single photographs. Photogrammetry is not only a good example of an inexpensive engagement strategy (there have been over 600,000 views of $3 \mathrm{D}$ models posted by the British Museum on Sketchfab) but it also revalorizes old photographs in new ways. The 3D model is not just a digital surrogate of a physical piece, but rather, this technology allows for engagement with rock art that would not even be possible on site. With 3D modelling, visitors can zoom, flip, read annotations, and listen to expert audio tracks and to actively engage at a volume and on a scale that could not be done at all at these sites in situ. 
Fig. 5 Engraved crocodile in the Messak Settafet, Libya (British Museum Reg. no. 2013, 2034.3106) (photo: TARA/David Colson

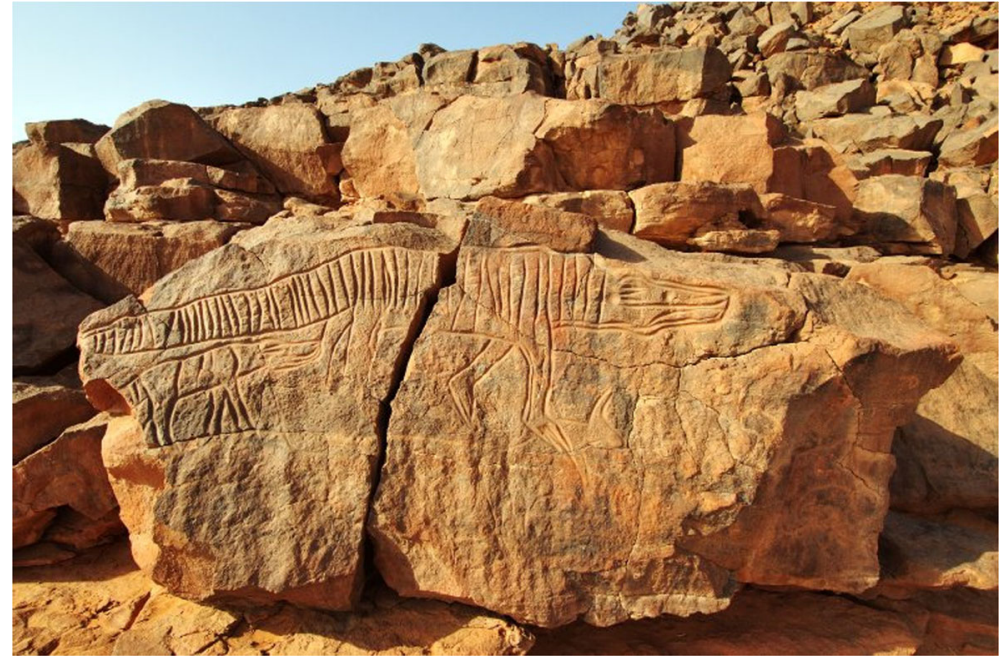

\section{Virtual Reality: Game Pass Shelter, South Africa}

The 3D models created allowed for important context of how the images of one site relate to each other; however, the project also wanted to ensure that visitors understand the importance of landscape and placement of images in the environment. Therefore, the project developed a Virtual Reality (VR) experience for visitors to understand context and landscape in rock art research. Building on the established VR work of the British Museum, it has proven to be an important tool for museums to engage the public with collections as well as contextualise objects within their landscapes (Rae and Edwards 2016).

Working with technical providers Soluis Heritage and the African Conservation Trust, the project developed a VR tour of Game Pass Shelter, a public rock art site in South Africa. This site was specifically chosen because of its well-known status in the uKhahlamba Drakensberg National Park, part of the larger UNESCO World Heritage site in the region, coupled with the existing security, monitoring and protection the visitors centre in the area could provide. Rock art is extremely susceptible to damage by both natural and human-made events, and our responsibility on the project lies in the protection of rock art sites. As such, the project did not want to create an easily downloadable virtual model of an unprotected site that could lead to its destruction by people with nefarious intentions.

The immersive experience combined $360^{\circ}$ photographs and 3D models of two of the main tableaus made using the previously mentioned techniques combined with collection landscape photos. Animations highlighting key figures and animals within the artworks were created to synch with the audio descriptions provided by the British Museum. It was built using Unity (www. unity3D.com), a free, open source game engine. The output was delivered in the form of a free mobile App available in iTunes and Android that could be downloaded directly to any smartphone, working with the internal gyroscope of the mobile. Utilising low-cost cardboard headset technology (such as Google Cardboard https://vr.google.com/cardboard/), a mobile phone, and standard earphones, the user can move intuitively and freely along a path from the base of the escarpment up to the rock shelter to look at the detail of the rock art site and turn to see the immersive views of the site; audio narration provides further information. A desktop version was also made to maximise access to the output http://vr.africanrockart.britishmuseum.org/ (Fig. 7).

Although more accurate models can be created using full virtual reality headsets, such as Occulus Rift (Rae and Edwards 2016), the project did not want cost, internet bandwidth speeds or access to the headset technology to act as a barrier. Virtual reality allows visitors to understand the context in which the rock art is placed in the landscape. Additionally, it gives visitors the chance to virtually travel to sites that would otherwise not be able to be reached, due to distance or conservation reasons (Milekic 2007: p. 370). By using cardboard technologies and mobile phones, it also allows for a greater access to the collection to those who cannot afford or get access to full VR headsets. 


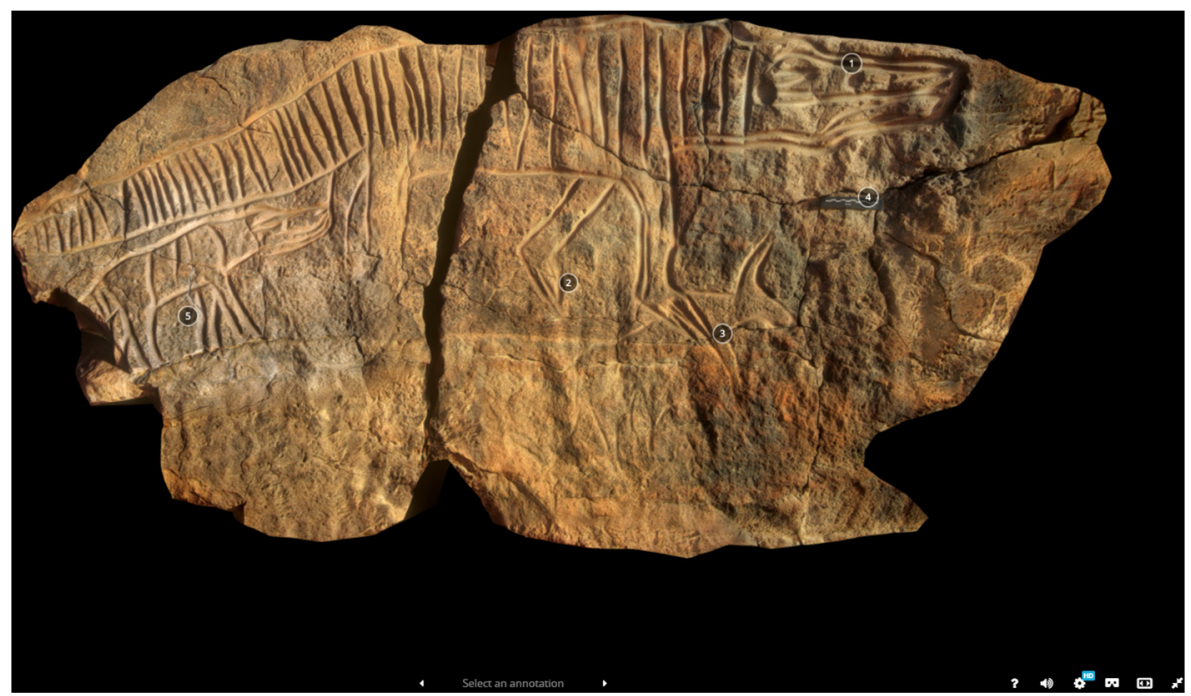

Fig. 6 3D model of a crocodile from Libya with annotations made by ARAIP on Sketchfab https://skfb.ly/FoRI

\section{D Printing}

As an entirely digital project, online and technical outputs were the main form of engagement. However, it was important to think of how ARAIP could bring the digital back into the physical museum. The project's experiments with 3D modelling have enabled 3D printing; an invaluable tool in the case of rock art to express the idea of three-dimensionality in a collection that is, by origin, two-dimensional. The costs of $3 \mathrm{D}$ printing can be prohibitive, but increasingly these costs are falling and cost-effective options will be a key catalyst among museum and heritage institutions driving widespread adoption. Nevertheless, the project was eager to explore how engagement could be brought back into the physical sphere and used 3D printing to help visitors understand the digital objects.

This technology has changed the way audiences can engage with the collections. 3D printing can give depth, context and dimension to objects that cannot be displayed using traditional museological methods (Anderson and Antoine 2017). By using these new technologies, curators are able to give a greater breadth and depth of the story of this object. Experimentation with $3 \mathrm{D}$ printing of some of the models proved a successful way for public engagement. Working with ThinkSee3D (www.thinksee3D.com), a company specialising in $3 \mathrm{D}$ printing for the heritage and natural

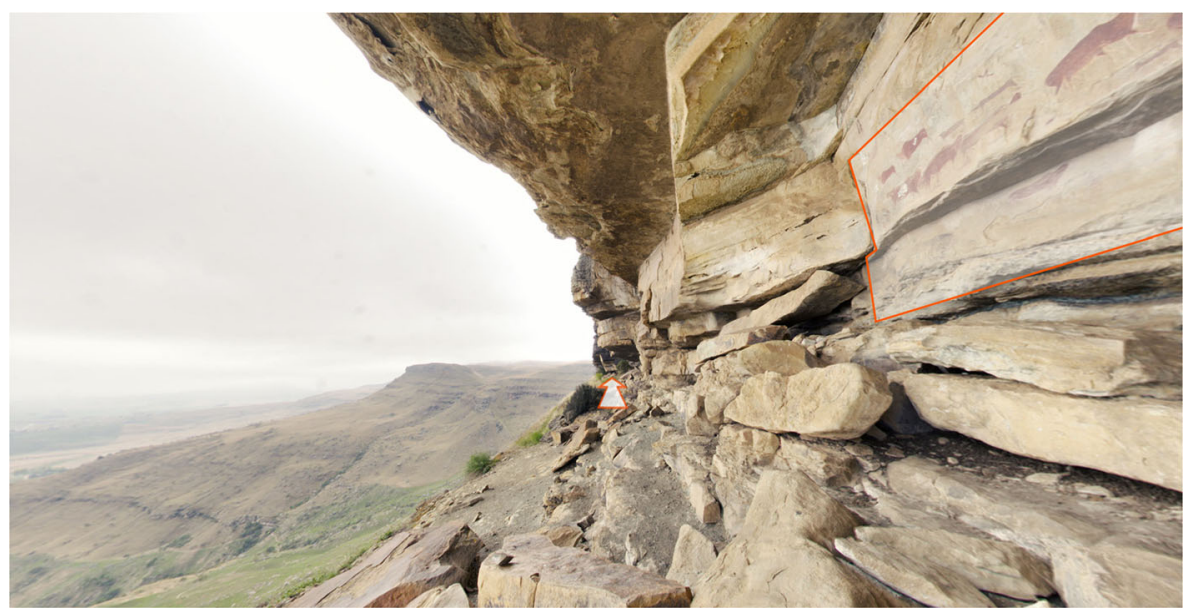

Fig. 7 Screenshot of the Game Pass Shelter VR app and desktop interactive http://vr.africanrockart.britishmuseum.org/ 
history industry, several 3D prints were created using a professional colour gypsum/acrylic 3D printer (a ProJet $\times 60$ ). This $3 \mathrm{D}$ printing technology was selected to replicate the rock art as it is particularly good at simulating the texture and colour of stone surfaces (Figs. 8 and 9).

These $3 \mathrm{D}$ prints proved especially useful for outreach programmes for differently abled visitors to the Museum. Working with the Access and Equality Manager at the Museum, handling and touch sessions were held for blind and partially sighted visitors on the theme of rock art: one on southern African rock art (tying in with several concurrent exhibitions on southern Africa at the Museum) and the other on Saharan rock art (Fig. 10). The use of gypsum in the printing process gave a stonelike feel, which added to the accuracy. Supplementary informative models were printed, including 3D prints of the animals represented in the engravings and "reduced noise" raised bas-relief outlines of the engravings. This allowed for blind and partially-sighted visitors to better understand the positioning and body-type of the animals represented in the rock art site.

\section{The Challenge of Obsolescence}

Both a great opportunity and challenge of digital outputs for audience engagement is the fast paced nature of the industry. Digital technologies, especially social media and online outputs for engagement and education, show that audiences can be inconsistent in which platforms are used, and shifts caused by disruptive technologies can change overnight (DePietro 2013). Brand new technology can be completely obsolete in a matter of years (Swaminathan 2011), if not months. For example, some software, platforms, and social media that the project was able to use in Year 4 did not exist in Year 1.

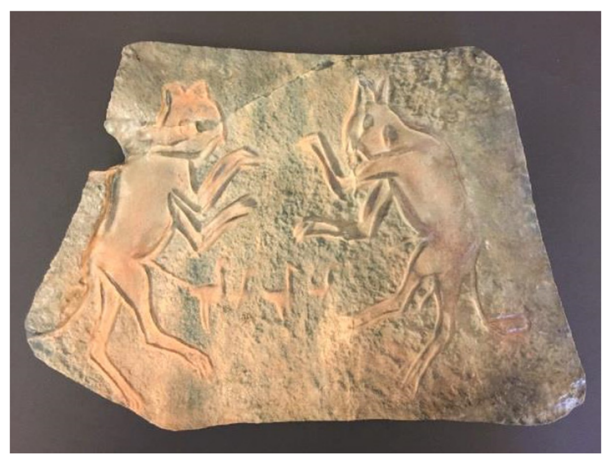

Fig. 8 3D print of the Fighting Cats, Libya. (photo: E. Galvin)

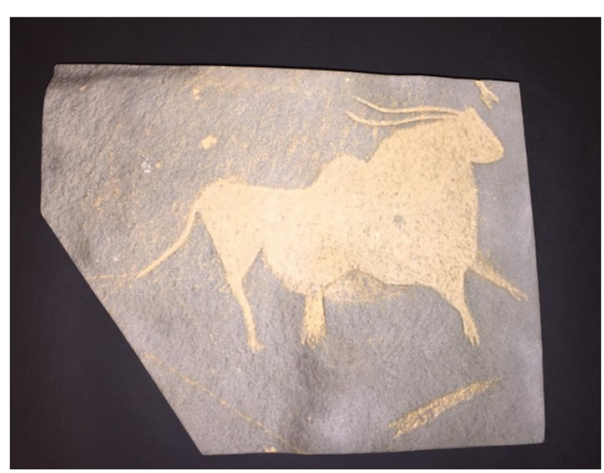

Fig. 9 3D print of engraved eland, South Africa (Right). (photo: E. Galvin)

Undoubtedly, by the time this paper reaches publication a new technology or open source platform will be developed that makes digital engagement easier or more exciting. Adapting to this rapid change in technology and discontinuity is a continual challenge for digital projects.

This is exemplified in three free public lectures at the British Museum given by rock art specialists in 2015 and broadcast live via Periscope with a Q\&A session via Twitter (Fig. 11). Developed at the time of the lectures, Periscope was at its height of popularity, and broadcasting live from a mobile device was still relatively novel (Pierce 2015a). Periscope allowed for free, low bandwidth, worldwide access to the lectures and reactive discussion from across the world, and the three aforementioned lectures provided a good example of this with participants from Europe, the Americas, Africa, and Asia asking questions to the guest speakers. At the time of broadcast, Periscope was a disruptive technology that was rapidly becoming popular; the founders announced in August 2015 it had 10 million viewers watching 40 years' of live-streamed video a day (Beykpour et al. 2015). Periscope used relatively inexpensive technologies including a smartphone and a Twitter account, and provided the opportunity for worldwide audiences to engage with the collection, and who might never be able to visit the Museum in person. However, later in 2015 FacebookLive was introduced, and the juggernaut of 1.5 billion Facebook users quickly eclipsed Periscope as a go-to broadcastlive technology with the sheer number of views and user numbers (Pierce 2015b). The British Museum as a whole shifted to FacebookLive in the past 2 years to reflect this, demonstrating how disruptive technologies can be harnessed for immediate use, but not necessarily 
Fig. 10 Blind and partially sighted visitors touch a $3 \mathrm{D}$ print of an engraving from Twyfelfontein Ui- Ais Namibia during a British Museum rock art access event. (photo: E. Galvin)

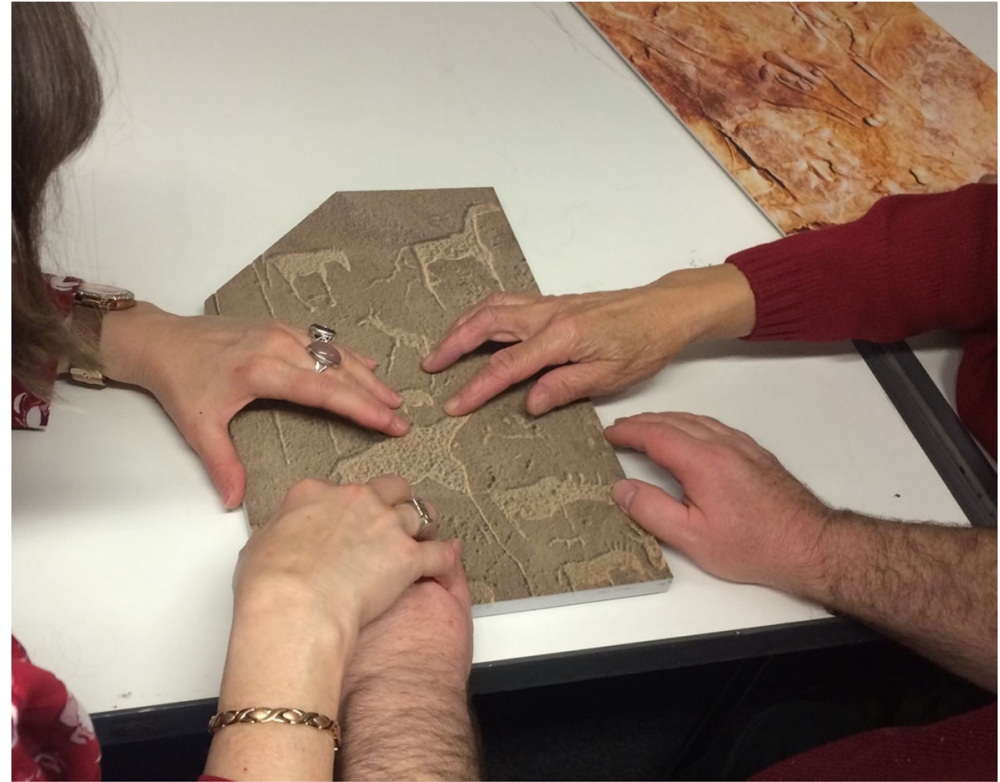

for a long-term strategy. Now, with the addition of YouTubeLive to the mix (Pierce 2015c), the challenges of choosing which technology will last long term, and accepting that working with one may have implications in the near future presents a very real, and complex challenge.

Because of this, digital projects need to be prepared to quickly adapt and change their outputs based on several factors that are outside of their control. For example, in 2015, the project used SoundCloud to narrate information about particular rock art sites, embedding the audio in the website and providing the opportunity to share on social media. However, as with many new start-ups, SoundCloud faced an economic crisis in 2017 that called into question the future of the site (Parham 2017). In response to this threat, the project transferred the audio files to Sketchfab to act as a narrative accompaniment to the interactive $3 \mathrm{D}$ models. While the future of SoundCloud is still unknown, the capricious nature of digital technology requires projects to adapt and act responsively.

It is impossible to accurately predict such a rapidly changing and evolving industry, but if the ultimate goal is maximising engagement and education, projects need to harness the popularity and novelty of a platform while it lasts (Grove 2011), even if it does not end up being the long-term agreed output. Despite this, fortunately, many digital outputs and platforms are free or low-cost, so projects are not losing excessive amounts of money with experimentation. It is this experimentation and adaptability that proves a digital project successful.

\section{Lessons for the Future}

The use of digital technology in the study of African rock art has brought many traditional museological challenges to the forefront, such as accessibility, preservation/ conservation, community engagement, understanding audiences, and outreach, to name a few. The themes of these challenges are felt across the continent and in a variety of contexts, from pure archaeological fieldwork settings to database management thousands of miles away.

The use of new technologies has created several diametrically opposed challenges that require new and everchanging creative solutions. Digital technologies have both increased access and awareness for the preservation of rock art sites, but also conversely, can lead to damage and destruction if sites have too many visitors without proper regulation (Deacon et al. 2018, this issue). Highresolution outputs, such as $3 \mathrm{D}$ scans and other digital work, can lead to further study and advancement of research; however, it also can contribute to widening the digital divide as local and source communities in Africa do not have the broadband and technological capacity to access it (Challis 2018; Namono 2018; Quesada 2018, 


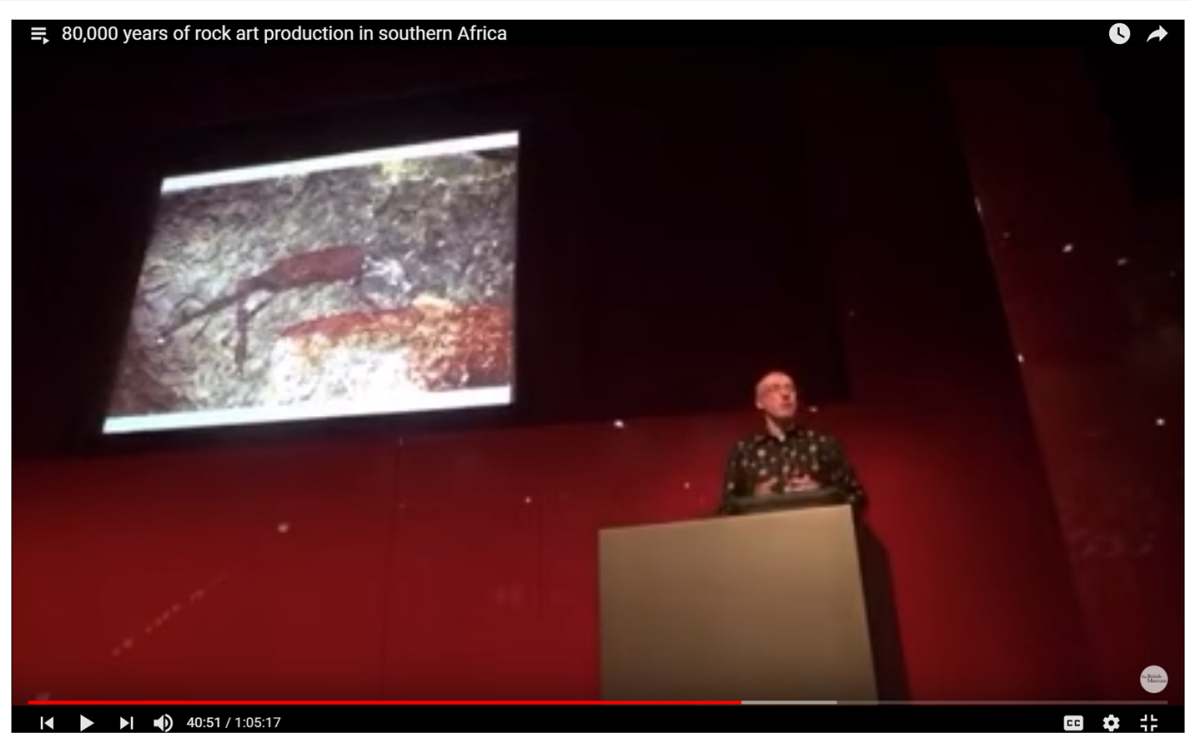

Fig. 11 Professor Benjamin Smith (University of Western Australia) giving a free lecture " 80,000 Years of Rock Art Production in Southern Africa" at the British Museum on 21 September 2015 that was broadcast live via Periscope, then later put on YouTube https://youtu.be/B1Xa5IuHVnY this issue). Databases can provide easily researchable data sets for study, but often these are only published in English, or another European language, which can limit its reach and even potentially alienate local communities who speak alternate languages, something the ARAIP project team are acutely aware of, as are the AAArC team and others (Lenssen-Erz et al. 2018, di Lernia 2018, this issue).

Digital Humanities projects have been criticised for being elitist, necessarily requiring generous funding, and thus the domain of only a few major institutions (Berry and Fagerjord 2017: p. 248). For museums with limited and diminishing resources, responding to the rapidly changing digital market is challenging. Cognisant of these challenges, the aim has been to capitalise on this position, to explore the digital possibilities and how low cost or no cost digital solutions can be utilised to present and promote the collection; and to share experiences with other institutions.

These points are not to discourage the use of new digital technologies, but rather encourage the application of traditional museum theory in these instances. An important and unexpected outcome from this project has been the finding that traditional curatorial practices, in association with digital technologies, may go some way to facilitating engagement with, and for, rock art research and rock art researchers in Africa. This includes carefully and methodically thinking about storage, intuitive and methodical cataloguing, audience reach, the scope of information with limited resources, translating research (both linguistically into local languages, and colloquially in making language choice accessible to non-scholars), and how this technology can be accessed by local and source communities. From DStretch to photogrammetry to social media, these technologies have proven invaluable to the advancement of African rock art research, to both scholarly and general audiences alike. But it requires a fundamental shift in approach: digitization and the use of digital technologies is not a destination, but rather a long journey that is going to be filled with several unavoidable pitfalls. Databases need continued curation, scans need updating and backup, social media needs to be posted regularly and generate followers to be effective.

Digital collections are requiring curators to reconceive traditional museological practices in terms of curation, preservation and audience engagement, while rock art researchers are required to act as curators of their own digital collections, both of whom can benefit from the digital platforms available for audience engagement, locally and globally. The advantage of these disciplinary adjacencies is both significant and substantial for future collaboration. Only by encouraging open access and sharing of successful, and even not so successful, outputs can the field truly harness the potential of these technologies in generating interest, preservation and research in Africa's rock art traditions. 
Acknowledgements The Authors would especially like to thank The Arcadia Fund, who have generously supported the African Rock Art Image Project, the Trust for African Rock Art (TARA) who donated the collection, and Dr. Lissant Bolton, Keeper of the Department of Africa, Oceania, and the Americas and Dr. John Giblin, Head of Africa at the British Museum for their support. This project could not have been successful without the existing work and collaborative scholarship of many rock art projects and databases throughout the world, and especially that of Professor David Pearce, Azizo Da Fonseca, and all staff and researchers at SARADA and the Rock Art Research Institute at the University of Witwatersrand. Additionally, the Authors would like to thank all the attendees, presenters, and participants of the "African Rock Art: Research, Digital Outputs and Heritage Management" conference held at the British Museum in November 2016, from which the idea of this entire publication came from.

Funding Information The African Rock Art Image Project at the British Museum is funded by The Arcadia Fund (Grant 3357).

\section{Compliance with Ethical Standards}

Conflict of Interest The authors declare that they have no conflict of interest.

Open Access This article is distributed under the terms of the Creative Commons Attribution 4.0 International License (http:// creativecommons.org/licenses/by/4.0/), which permits unrestricted use, distribution, and reproduction in any medium, provided you give appropriate credit to the original author(s) and the source, provide a link to the Creative Commons license, and indicate if changes were made.

\section{References}

Abt, J. (2006). The origins of the public museum. In S. MacDonald (Ed.), A companion to museum studies (pp. 115-134). Oxford: Wiley-Blackwell.

Allen, P., Feiner, S., Meskell, L., Ross, K., Troccoli, B., Smith, B., Henko, H., Ishak, J. (2004). Digitally modeling, visualizing and preserving archaeological sites. Proceedings of the 2004 Joint ACM/IEEE Conference on Digital Libraries. Tucson, AZ, USA.

Anati, E. (2004). Introducing the world archives of rock art (WARA): 50.000 years of visual arts. New discoveries, new interpretations, new research methods, XXI Valcamonica Symposium (pp. 51-69). Capo di Ponte: Edizioni del Centro.

Anderson, J., \& Antoine, D. (2017). Scanning Sobek: Mummy of the crocodile god. In S. Ikram \& S. Porcier (Eds.), Proceedings of the ISAAE 2016-1st International Symposium on Animals in Ancient Egypt. 1-3 June 2016 Lyon (France). Leiden: Sidestone Press.

Ashley, M., \& Perlingieri, C. (2012). Engaging a new digital citizenry. In J. McDonald \& P. Veth (Eds.), A companion to rock art (pp. 660-669). New Jersey: Wiley-Blackwell.

Ayemoba, A. (2016). Africa has moved from mobile first to "mobile only market". Resource document. Africa Business
Communities. http://africabusinesscommunities. com/features/africa-has-moved-from-mobile-first-to-mobileonly-market.html. Accessed 02 August 2017.

Bennet, I., Devlin, G., \& Harrington, C. (2016). Corca dhuibhne 3D. Archaeology Ireland, 30(2), 17-20.

Berry, D. M., \& Fagerjord, A. (2017). Digital humanities: Knowledge and critique in a digital age. Cambridge: Polity Press.

Bertacchini, E., \& Morando, F. (2013). The future of museums in the digital age: New models for access and use of digital collections. International Journal of Arts Management, 15(2), 60-72.

Beykpour, K., et al. (2015). Periscope, by the numbers. Medium, 12 August 2015. https://medium.com/periscope/periscope-bythe-numbers-6b23dc6a1704. Accessed 02 September 2017.

Brin, A., McManamon, F. P., \& Niven, K. (2013). Caring for digital data in archaeology: A guide to good practice. Oxford: Oxbow Books.

British Museum (2005). Report and accounts for the year ended 31 March 2005. London: The British Museum. https://www. britishmuseum.org/pdf/TAR04-05.pdf. Accessed September 2017.

British Museum (2015). Report and accounts for the year ended 31 March 2015. London: The British Museum. http://www. britishmuseum.org/PDF/BM-report-and-accounts-20142015.pdf. Accessed September 2017.

British Museum Annual Review (2017). London: HMSO. Ordered by The House of Commons to be printed on 13 July 2017. https://www.gov.uk/government/publications. Accessed 12 October 2017.

Cameron, F. (2007). Beyond the cult of the replicant: Museums and historical digital objects: Traditional concerns, new discourses. In F. Cameron \& S. Kenderdine (Eds.), Theorizing digital cultural heritage: A critical discourse. Cambridge: MIT Press.

Challis, S. (2018). Collections, collecting and collectives: Gathering heritage data with communities in the mountains of Matatiele and Lesotho, southern Africa. African Archaeological Review. https://doi.org/10.1007/s10437-0189299-x.

Coffee, K. (2007). Audience research and the museum experience as social practice. Museum Management and Curatorship, 22(4), 377-389.

Conway, P. (2010). Preservation in the age of google: Digitization, digital preservation, and dilemmas. The Library Quarterly: Information, Community, Policy, 80(1), 61-79.

Crooke, E. (2006). Museums and community. In S. MacDonald (Ed.), A companion to museum studies (pp. 170-185). Oxford: Wiley-Blackwell.

Cunningham, A. (2008). Digital Curation/Digital Archiving: A View from the National Archives of Australia. The American Archivist, 71(2), 530-543.

Deacon, J., Wiltshire, N., \& du Plessis, R. (2018). Designing digital recording for volunteers in rock art surveys, management plans and public outreach in the Cederberg, South Africa. African Archaeological Review. https://doi. org/10.1007/s10437-018-9293-3.

DePietro, P. (2013). Social media and collaborative learning. Transforming Education with New Media, 465, 47-62.

di Lernia, S. (2018). A (digital) future for Saharan rock art? African Archaeological Review. https://doi.org/10.1007 /s10437-018-9290-6. 
Evans, T.N.L. (2015). A reassessment of archaeological grey literature: Semantics and paradoxes, resource document. Internet Archaeology, 40. https://doi.org/10.11141/ia.40.6.

Falk, J. H. (2016). Identity and the museum visitor experience. London: Routledge.

Fritz, C., \& Tosello, G. (2007). The hidden meaning of forms: Methods of recording paleolithic parietal art. Journal of Archaeological Method and Theory, 14(1), 48-80.

Galvin, E., de Torres, J., Anderson, H., \& Suzman, V. (2017). The African Rock Art Image Project: Cataloguing rock art at the British Museum. In M. Sahnouni, S. Semaw, \& J. Rios Garaizar (Eds.), Proceedings of the II Meeting of African Prehistory (pp. 567-596). Burgos: Centro Nacional de Investigación sobre la Evolución Humana.

Grove, T. (2011). History bytes: Institutional change through new media. History News, 66(3), 5-6.

GSMA Report (2016). The Mobile Economy Africa 2016. https://www.gsmaintelligence.com/research/2016/07/themobile-economy-africa-2016/569/. Accessed 02 January 2018.

Gu, M. (2012). Engaging museum visitors through social media: Multiple case studies of social media implementation in museums. MA thesis, Ohio State University.

Henning, M. (2006). New media. In S. MacDonald (Ed.), A companion to museum studies (pp. 302-318). Oxford: Wiley-Blackwell.

Henry, L. (2007). A history of removing rock art in South Africa. South African Archaeological Bulletin, 62(185), 44-48.

Kaneko, M. (2015). Collections and archives on Ethiopian studies in the Frobenius Institut. Nilo-Ethiopian Studies, 20, 33-40.

Kaplan, F. E. S. (2006). Making and remaking national identities. In S. MacDonald (Ed.), A companion to museum studies (pp. 152-169). Oxford: Wiley-Blackwell.

Kelly, L., \& Fitzgerald, P. (2011). Cooperation, collaboration, challenge: How to work with the changing nature of educational audiences in museums. In N. Mockler \& J. Sachs (Eds.), Rethinking educational practice through reflexive inquiry. Professional learning and development in schools and higher education (Vol. 7, pp. 77-88). Dordrecht: Springer.

Kohn, K.-H. (1998). Das Frobenius-Institut an der Johann Wolfgang Goethe-Universität. 1898-1998. Frankfurt am Main: Frobenius Institut.

Kuper, R. (Ed.). (2013). The cave of beasts: A rock art site in the Gilf Kebir (SW Eypt). Cologne: Africa Praehistorica.

Langlais, D. (2005). Cybermuseology and intangible cultural heritage. Intersection conference. 2005, York University, Toronto. http://www.yorku.ca/topia/docs/conference/Langlais.pdf. Accessed 7 October 2017.

Lee, K. M. (2004). Presence: Explicated. Communication Theory, 14(1), 27-50.

Lenssen-Erz, T., Fäder, E., Jesse, F., \& Wilmeroth, J. (2018). Managing digital rock art: The African Archaeology Archive Cologne (AAArC). African Archaeological Review, 35(2).

Leschenko, A. (2015). Digital dimensions of the museum: Defining cybermuseology's subject of study. International Journal of the ICOM International Committee for Museology (ICOFOM) Study Series, 43, 237-241.

MacDonald, S. (2006). Collecting practices. In S. MacDonald (Ed.), A companion to museum studies (pp. 81-97). Oxford: Wiley-Blackwell.
Message, K., \& Witcomb, A. (2015). Introduction: Museum theory, an expanded field. In K. Message and A. Witcomb (Eds.), Museum theory, The International Handbooks of Museum Studies, 1 (pp. xxv-lxiii). Oxford: Wiley.

Milekic, S. (2007). Towards tangiable virtualities: Tangialities. In F. Cameron \& S. Kenderdine (Eds.), Theorizing digital cultural heritage: A critical discourse (pp. 369-388). Cambridge: MIT Press.

Namono, C. (2018). Digital technology and a community framework for heritage rock art tourism, Makgabeng Plateau, South Africa. African Archaeological Review. https://doi. org/10.1007/s10437-018-9298-y.

National Research Foundation (NRF). (2009). An audit of South African digitisation initiatives: Ongoing and planned. Pretoria: National Research Foundation.

Parham, J. (2017). Soundcloud isn't dead yet, but its greatest legacy could soon be. Wired Magazine 27 July 2017. https:/www.wired.com/story/soundcloud-new-genres/. Accessed 02 October 2017.

Pett, D. (2012). Use of social media within the British Museum and the museum sector. In C. Bonacchi (Ed.), Archaeology and digital communication: Towards strategies of public engagement (pp. 83102). London: Archetype Publications.

Pierce, D. (2015a). Twitter's Periscope app lets you livestream your world. Wired Magazine, 26 March 2015. https://www. wired.com/2015/03/periscope/. Accessed 10 October 2017.

Pierce, D. (2015b). Facebook live video is Facebook at its most Facebook. Wired Magazine, 4 December 2015. https://www. wired.com/2015/12/facebook-live-video-is-facebook-at-itsmost-facebook/. Accessed 10 October 2017.

Pierce, D. (2015c). YouTube is the sleeping giant of livestreaming. Wired Magazine, 17 August 2015. https://www.wired. com/2015/08/youtube-sleeping-giant-livestreaming/. Accessed 10 October 2017.

Poyner IV, F. (2010). Copyright issues, rights management, and licensing programs for digital collections by historical institutions. History News, 65(3), 1-8.

Preziosi, D., \& Farago, C. (Eds). (2003). Grasping the world: The idea of the museum. Ashgate, 2003.

Prezosi, D. (2006). Art history and museology: Rendering the visible legible. In S. Macdonald (Ed.), A companion to museum studies (pp. 60-73). Oxford: Wiley-Blackwell.

Quesada, E. (2018). Empowering the local Saharawi people. Training for rock art documentation in Western Sahara (DARSSO project). African Archaeological Review, 35(2).

Rae, J., \& Edwards L. (2016). Virtual reality at the British Museum: What is the value of virtual reality environments for learning by children and young people, schools, and families? Published conference paper (28 January 2016), Museums and the Web Conference 2016. http://mw2016. museumsandtheweb.com/paper/virtual-reality-at-the-britishmuseum-what-is-the-value-of-virtual-reality-environmentsfor-learning-by-children-and-young-people-schools-andfamilies/. Accessed 11 October 2017.

Richards, J. D., Niven, K., \& Jeffrey, S. (2013). Preserving our digital heritage: Information systems for data management and preservation. In E. Ch'ng, V. Gaffney, \& H. Chapman (Eds.), Visual heritage in the digital age (pp. 311-326). London: Springer-Verlag. 
Roberts, A. (1991). The standards work of the museum documentation association. History News, 46(4), 24-25.

Rodéhn, C. (2015). Theorizing democratization of heritage: The consequences of performance. In K. Lafrenz \& T. Rico (Eds.), Heritage keywords: Rhetoric and redescription in cultural heritage. Boulder: University of Colorado Press.

Ross, C., \& Terras, M. (2011). Scholarly informationseeking behaviour in the British Museum Online Collection. In J. Trant \& D. Bearman (Eds). Museums and the Web 2011: Proceedings. Toronto: Archives \& Museum Informatics. Published March 31, 2011. https://www.museumsand theweb.com/mw2011 /papers/scholarly_information_seeking_behaviour_in the.html. Accessed 11 October 2017.

Schubert, K. (2009). The curator's egg: The evolution of the museum concept, from the French revolution to the present day. London: Ridinghouse.

Stein, J., Garibay, C., \& Wilson, K. (2013). Engaging immigrant audiences in museums. Museums and Social Issues: A Journal of Reflective Discourse. https://doi.org/10.1179 /msi.2008.3.2.179.
Swaminathan, N. (2011). Digging into technology's past. Archaeology, 64(4), 30-33.

Szrajber, T. (2007). Collection Online: The British Museum Collection Database Goes Public. In A. Bentkowska-Kafel, T. Cashen, \& H. Gardiner (Eds.), Digital Archive Fever, Proceedings of the 23rd CHArt Conference held on 8th-9th November 2007. Birkbeck College, London: Computers and the History of Art Online Proceedings, (Vol. 10). www.chart.ac.uk. Accessed 14 November 2015.

Szrajber, T. (2008). Public access to collection databases: The British Museum Collection Online (COL): A case study. Annual Conference of CIDOC. Athens. http://network.icom. museum/cidoc/archives/past-conferences/2008-athens/. Accessed 14 November 2015.

Taylor, J., \& Gibson, L. K. (2017). Digitisation, digital interaction and social media: Embedded barriers to democratic heritage. International Journal of Heritage Studies. https://doi. org/10.1080/13527258.2016.1171245.

Urcia, A., Darnell J.C., Darnell, C.M., \& Zaia, S. E. 2018. From plastic sheets to tablet PCs: A digital epigraphic method for recording Egyptian rock art and inscriptions. African Archaeological Review. https://doi.org/10.1007/s10437-018-9297-z. 